\title{
FORMULASI KEBIJAKAN KOMUNIKASI UNTUK PELAKSANAAN PROGRAM PEMBANGUNAN KESEHATAN
}

\author{
Communication Policy Formulation for the Implementation of \\ Health Programs
}

\author{
Aji Muhawarman', Dumilah Ayuningtyas', Misnaniarti² \\ ${ }^{1}$ Departemen Administrasi dan Kebijakan Kesehatan, Fakultas Kesehatan Masyarakat \\ Universitas Indonesia \\ ${ }^{2}$ Bagian Administrasi Kebijakan Kesehatan, Fakultas Kesehatan Masyarakat Universitas \\ Sriwijaya \\ (muhawarman@gmail.com)
}

\begin{abstract}
ABSTRAK
Komunikasi adalah faktor penting dalam keberhasilan implementasi kebijakan dan program pemerintah. Beberapa temuan hasil riset dan pemberitaan di media menunjukkan bahwa masih terdapat kebijakan dan program kesehatan yang belum berhasil mencapai target, yang mungkin disebabkan karena tidak berjalannya fungsi komunikasi secara optimal. Oleh karena itu, tujuan penelitian ini untuk menganalisis proses kebijakan dan menghasilkan formulasi kebijakan komunikasi publik (berupa rancangan pedoman). Desain penelitian deskriptif menggunakan metodologi kualitatif, pengumpulan data dilakukan melalui wawancara mendalam, focus group discussion dan telaah dokumen. Hasil penelitian menunjukkan fungsi komunikasi yang dijalankan telah mengalami kemajuan, tetapi masih ada permasalahan dan tantangan, baik internal maupun eksternal, antara lain belum memiliki pedoman komunikasi yang dijadikan acuan dalam mengarahkan, mengendalikan dan mengevaluasi pelaksanaan tugas dan fungsinya sehari-hari dan mengatur hal-hal kehumasan yang mendasar dan menyeluruh. Disimpulkan bahwa fungsi komunikasi yang dijalankan Unit Hubungan Masyarakat Kementerian Kesehatan belum berjalan secara optimal. Direkomendasikan segera adanya pedoman yang mengatur fungsi komunikasi secara terintegrasi dan komprehensif dalam hal kelembagaan, kegiatan, tata laksana kerja dan sumber daya. Hasil penelitian ini diharapkan akan diadopsi menjadi regulasi dalam mendukung pelaksanaan program pembangunan kesehatan di Indonesia.
\end{abstract}

Kata kunci: Formulasi, kebijakan, komunikasi, hubungan masyarakat

\section{ABSTRACT}

Communicationis animportant factor inthe successful implementation ofgovernment policies and programs. Some findings fromprevious studiesandnews in mediaindicatethatthere arehealth policies and programsthathave notsucceeded inachievingtheirtargets, which may be due tothe ineffectiveness ofthe communication function. Therefore, the aim of this research was to analyze policy process and produce a formulation of communications policy (in the form of a guideline draft). Using qualitative methodology with descriptive type, data collection was conducted through in-depth interviews, focus group discussion, and literature analysis. The results showed that the communication functions that have been conducted haveprogressed, but there were still problems and challenges, both internally and externally. This includes the absence of a communications guidelineto be referenced in directing, controlling, and evaluating the implementation of tasks and daily functions as well as regulating matters of public relations fundamentally and thoroughly. It was concluded that communication functions executed by the Public Relations Unit of the Ministry of Health have not been optimally implemented. It is recommended to immediately realize guidelines to manage the communication functions in an integrated and comprehensive way in terms of institutions, activities, governance, and resource. It is hoped that the findings of this study will be adopted into regulation in support of the implementation of health development programs in Indonesia.

Keywords: Formulation, policy, communication, public relation 


\section{PENDAHULUAN}

Keberhasilan implementasi sebuah kebijakan atau program pembangunan ditentukan oleh banyak faktor, komunikasi menjadi salah satu determinan. ${ }^{1}$ Begitu pula dalam pelaksanaan pembangunan kesehatan di Indonesia. Negara kita masih dihadapkan pada sejumlah masalah yang berkaitan dengan derajat kesehatan masyarakat. Permasalahan yang timbul diantaranya disebabkan minimnya sosialisasi terhadap kebijakan dan program kesehatan.

Contohnya pada program imunisasi, masih ada beberapa bayi tidak mendapatkan imunisasi dasar secara lengkap. Berdasarkan Riset Kesehatan Dasar 2013 walaupun sudah menunjukkan ada perbaikan angka cakupan imunisasi lengkap dari tahun 2007. Akan tetapi masih dijumpai $32,1 \%$ yang diimunisasi tetapi tidak lengkap, serta $8,7 \%$ yang tidak pernah diimunisasi, dengan alasan karena takut panas, sering sakit, keluarga tidak mengizinkan dan sibuk/repot $( \pm 80 \%)$, sisanya karena tempat imunisasi jauh, tidak tahu tempat imunisasi. ${ }^{2}$ Ketidaktahuan akan manfaat imunisasi yang mengakibatkan timbulnya keengganan untuk mengimunisasi anaknya menunjukkan kegagalan proses komunikasi kebijakan kesehatan kepada masyarakat.

Begitu juga persentase ASI eksklusif dalam 24 jam terakhir pada bayi umur 6 bulan meningkat dari $15,3 \%$ tahun 2010 menjadi $30,2 \%$ pada tahun 2013. ${ }^{2}$ Hasil Survei Demografi dan Kesehatan Indonesia (SDKI) tahun 2012, menunjukkan persentase pemberian ASI eksklusif terus menurun setelah dua bulan pertama. Lebih dari 7 diantara 10 anak umur 4-5 bulan menerima makanan tambahan (44\%), air putih (8\%), susu atau cairan tambahan lainnya $(8 \%)$ sebagai tambahan dari ASI atau sepenuhnya sudah disapih $(13 \%){ }^{3}$ Kondisi seperti itu bisa disebabkan kurangnya pendidikan kesehatan yang menyebabkan rendahnya pengetahuan sehingga memengaruhi perilaku ibu dalam memberikan ASI. ${ }^{4}$

Global Adult Tobacco Survey tahun 2011 melaporkan fakta bahwa sekitar separuh dari popu- lasi (usia 15 tahun ke atas) mengetahui informasi tentang anti rokok dan hampir $70 \%$ tahu tentang peringatan kesehatan pada bungkus rokok. Lebih dari $80 \%$ dari perokok juga menyadari dampak rokok akan mengakibatkan penyakit seri- us. Namun, semua itu tidak lantas berkorelasi erat dengan kebiasaan merokok, karena ternyata hanya sekitar 30\% yang berpikir untuk berhenti merokok setelah melihat iklan anti rokok, membaca peringatan kesehatan dan mengetahui dampak buruknya. ${ }^{5}$

Selain soal rokok, Riskesdas 2013 juga menghasilkan temuan tentang rumah tangga yang pernah mendengar atau mengetahui mengenai Obat Generik (OG) secara nasional sebanyak 31,9\%. Dari jumlah tersebut, sebagian besar $(85,9 \%)$ tidak memiliki pengetahuan yang benar tentang $O G$ dan yang menunjukkan pengetahuan benar tentang OG sangat rendah, baik di rumah tangga perkotaan maupun di pedesaan. Obat generik menjadi produk inferior yang hanya dipersepsikan sebagai obat murah. ${ }^{2}$ Begitu juga pada kepemilikan jaminan kesehatan, dilaporkan sekitar $63 \%$ laki-laki belum memiliki jaminan kesehatan sama sekali (69\% pada perempuan). ${ }^{3}$

Melihat gambaran segala permasalahan, hambatan, tantangan yang dihadapi dalam pelaksanaan program-program kesehatan, dapat dikatakan sebenarnya peran komunikasi memiliki andil yang besar dalam suksesnya implementasi sebuah kebijakan pemerintah atau dalam mengatasi krisis karena terjadinya kontroversi dari kebijakan. Dalam model implementasi kebijakan menurut Edwards, terdapat empat faktor krusial yang menentukan keberhasilan implementasi sebuah kebijakan yakni komunikasi, sumber daya, kecenderungan/tingkah laku, dan struktur birokrasi. ${ }^{6}$

Fungsi komunikasi di Kementeian Kesehatan (Kemenkes) RI diamanatkan kepada Pusat Komunikasi Publik (Puskomblik) sebagaimana tertuang dalam Peraturan Menteri Kesehatan Nomor 1.144 Tahun 2010 tentang Organisasi dan Tata Kerja. ${ }^{7}$ Regulasi yang mengatur tentang fungsi kehumasan instansi pemerintah (melalui Permen-PAN Nomor 12 Tahun 2007 tentang Pedoman Umum Hubungan Masyarakat di Lingkungan Instansi Pemerintah) sudah ada sejak lama, tetapi pedoman tersebut tidak diterjemahkan ke dalam regulasi internal yang dapat dijadikan pedoman di lingkungan Kemenkes hingga dinas kesehatan dan unit vertikal Kemenkes se-Indonesia.

Kebijakan yang dibutuhkan belum tersedia karena selama ini belum pernah dilakukan evaluasi dan kajian, khususnya terhadap aktivitas hubung- 
an masyarakat yang telah dan akan dilakukan. Selain itu, belum adanya pedoman nasional yang seharusnya diterbitkan oleh Kementerian Komunikasi dan Informatika selaku penanggung jawab aktivitas komunikasi lembaga pemerintah.

Menurut Martson, seharusnya dalam kegia$\tan$ Public Relations (PR) menggunakan formula RACE (Research, Action Plan, Communication and Evaluation) artinya seorang praktisi/institusi PR seperti Puskomblik (Pusat Komunikasi Publik) Kemenkes harus tahu banyak tentang kondisi organisasi, program, khalayaknya dan komponen penunjang komunikasi lainnya sebelum meluncurkan program PR yang akan mendukung penuh implementasi sebuah kebijakan. ${ }^{8}$ Oleh karena itu, tujuan penelitian ini adalah menggali informasi lebih dalam dan menghasilkan sebuah rancangan instrumen kebijakan komunikasi publik yang diharapkan akan diformulasikan lebih lanjut dan diadopsi menjadi regulasi sehingga bisa menjadi salah satu referensi utama bagi upaya Komunikasi, Informasi dan Edukasi (KIE).

\section{BAHAN DAN METODE}

Penelitian ini menggunakan metode penelitian kualitatif melalui perspektif kebijakan. Pemilihan metode kualitatif karena informasi penelitian harus digali secara mendalam agar mampu mengangkat jawaban yang dicari atas permasalahan yang diteliti. ${ }^{9}$ Pengumpulan data pada tahun 2015 di Kementerian Kesehatan, Kementerian Komunikasi dan Informatika, Dinas Kesehatan, Universitas Indonesia, dan perusahaan swasta tertentu. Pemilihan informan dengan teknik purposive sampling berdasarkan asas kecukupan (adequacy) dan kesesuaian (approriateness). Informan kunci adalah pejabat dari instansi Kemenkes, Kementerian Kominfo, serta pakar dan praktisi dari beberapa instansi terkait (jumlah 7 orang), serta tokoh masyarakat, kader dan warga (6 orang).

Pengambilan data menggunakan wawancara mendalam semi terstruktur dan Focus Group Discussion (FGD), serta dari data sekunder berupa kepustakaan, dokumen peraturan perundangan, hasil riset yang memiliki keterkaitan dengan materi penelitian. Alat pengumpulan data selain peneliti sendiri juga dengan peralatan berupa: panduan wawancara, form informed consent, buku catatan, alat tulis, voice recorder, alat dokumen- tasi, dan peralatan lainnya. Kerangka teori disusun berdasarkan empat teori utama yakni: teori pembuatan kebijakan, teori agenda setting, teori segitiga kebijakan dan teori komunikasi. ${ }^{10-13}$ Penelitian ini dikembangkan mulai dari analisis situasi, kemudian tahapan pembuatan kebijakan dengan mengidentifikasi isu utama hingga formulasi kebijakan. Melalui proses ini dapat dihasilkan rekomendasi kebijakan berupa rancangan instrumen kebijakan komunikasi berdasarkan komponen komunikasi, yaitu: tujuan, komunikator, konten, media, komunikan dan strategi.

Validasi data hasil penelitian dilakukan dengan teknik triangulasi, yaitu triangulasi sumber data, triangulasi teori dan triangulasi metodologi. Tujuan triangulasi adalah untuk: a) meningkatkan validitas dan reliabilitas penelitian, b) meningkatkan ketepatan interpretasi, c) meningkatkan keyakinan bahwa data/informasi yang berhasil dikumpulkan adalah faktual. ${ }^{14}$ Selanjutnya data diolah dengan proses coding dan kategorisasi dari trans-krip wawancara dan FGD, kemudian dianalisis menggunakan teknik analisis isi (content analysis).

\section{HASIL}

Identifikasi analisis situasi yang dilakukan pada kondisi internal dan eksternal, dengan tujuan untuk mengetahui kelebihan dan kekurangan organisasi, peluang dan hambatan yang ada, kebutuhan yang sebenarnya, serta memperhatikan tuntutan dan dinamika yang terjadi di lingkungan sekitar. Ini dilakukan agar kebijakan yang dihasilkan dapat tepat sasaran dan solutif.

Secara umum pelaksanaan kebijakan dan program kesehatan telah mengalami kemajuan dari tahun ke tahun, meskipun masih ada yang belum diselesaikan. Faktor komunikasi (sosialisasi) pada kebijakan dan program yang diluncurkan pemerintah menjadi determinan yang menentukan program tersebut berhasil atau tidak. Seluruh informan berpendapat bahwa upaya komunikasi merupakan hal yang penting dalam proses implementasi kebijakan/program pemerintah termasuk bidang kesehatan, seperti pada petikan wawancara berikut:

\footnotetext{
“...hampir semua aktivitas kebijakan publik pemerintah mutlak harus didukung
} 
komunikasi cuma kadang komunikasi itu dianggap nomor sekian. Ketika program komunikasinya tidak menjadi prioritas tidak menjadi perhatian penuh akhirnya ya kebijakannya sama seperti yang anda tulis disini, selalu ada yang menunjukkan konflik...". (Informan 3)

Kelemahan fungsi komunikasi tersebut tentu bisa disebabkan oleh banyak faktor, terutama karena kendala yang dihadapi para praktisi komunikasi/kehumasan di Kemenkes dalam melaksanakan tugas dan fungsinya. Berdasarkan informasi darivmayoritas informan, diketahui kendala internal utama yang sering menghambat adalah ketersediaan sumber daya seperti SDM, anggaran dan sarana prasarana.

"Kalo Humas di pemerintahan saya melihatnya dari sisi SDM-nya kali ya. Karena yang sepanjang saya keliling dari departemen/instansi pemerintah itu bukan orang public relations". (Informan 4)

"Karena di struktur organisasinya gak ada, gak ada Humas, itu nempel di Sub bagian Umum. Boleh kita di sub-bag umum, tetapi kita punya kekuatan lagi kayak di fungsional. Dulu sempat Subbag Hukum dan Humas pada tahun 2000an, pada waktu masih pecah antara Dinas dan Kanwil. Akhirnya disempitkan organisasinya, akhirnya larinya ke umum". (Informan 7)

Hal yang dianggap menjadi penyebab masalah belum maksimalnya fungsi komunikasi adalah karena belum adanya pedoman komunikasi atau pedoman kehumasan yang menjadi panduan dalam mengarahkan dan mengendalikan kegiatan komunikasi antara Kemenkes dengan khalayaknya, seperti petikan wawancara berikut:

“...Sangat penting karena pedoman ini harus menjadi payung untuk pelaksanaan $\mathrm{Hu}$ mas, terutama untuk Humas di Kemenkes dan UPT-UPT. Jadi selama ini kita bekerja tidak berdasarkan suatu pedoman. Cuma ya itu menurut saya sangat terlambat, dengan (Puskom) berdiri sudah 8 tahun. Pedoman itu akan kita Permenkeskan, targetnya harus keluar tahun ini (2015)”. (Informan 1)
Apabila membandingkan antara target kegiatan yang ditetapkan dengan realisasi yang berhasil diraih, dapat dilihat terjadi peningkatan dari tahun ke tahun dan mengalami kemajuan berarti. Hal yang tidak kalah pentingnya juga target dan kegiatan tersebut telah sesuai dengan standar Humas pemerintah yang telah ditetapkan. Jika melihat visi, misi serta tujuan dan sasaran yang kemudian diterjemahkan dalam bentuk kegiatan dengan indikator kinerjanya, terlihat belum selaras/sinkron.

Puskomblik Kemenkes mengalami berbagai kendala dari sisi ketersediaan sumber daya manusia (SDM). Tahun 2014 terdapat pegawai sebanyak 61 orang, hanya ada 7 orang yang memiliki jabatan fungsional Pranata Humas, sehingga tidak dapat memenuhi standar minimal yang disyaratkan.

Selain SDM, sumber daya lain yang dibutuhkan adalah anggaran. Dari tahun ke tahun anggaran komunikasi publik porsinya tidak pernah melebihi dari 1\% total Anggaran Pendapatan dan Belanja Negara (APBN) Kementerian Kesehatan. Secara nominal jumlahnya fluktuatif tapi cenderung stabil yakni pada kisaran 40 miliar rupiah per tahun. Akan tetapi secara persentase bila dibandingkan dengan total anggaran Kemenkes kecenderungannya terus menurun sementara anggaran Kemenkes dalam kurun waktu 5 tahun terakhir terus meningkat. Situasi ini menunjukkan bahwa fungsi komunikasi belum menjadi prioritas anggaran bagi program dan unit kerja lainnya.

Masih banyak yang perlu dilakukan penataan pada pelaksanaan fungsi komunikasi tidak hanya soal juru bicara dan iklan. Ini semakin menegaskan bahwa kebijakan yang dilahirkan bersifat insidentil dan terfragmentasi, tidak memiliki sebuah kebijakan umum yang bisa dan seharusnya memayungi semuanya. Memperhatikan situasi tersebut, sudah waktunya bagi Puskomblik Kemenkes memiliki pedoman tersendiri tentang komunikasi/kehumasan di lingkungan Kemenkes yang dapat memberikan arah dan kendali bagi pelaksanaan fungsi komunikasi untuk saat ini dan seterusnya.

Analisis situasi eksternal dilakukan untuk memperkuat adanya desakan akan tersedianya semacam norma, standar atau prosedur kegiatan komunikasi dari pihak luar Puskomblik Kemenkes. Berdasarkan hasil FGD, informan menilai 
pentingnya strategi komunikasi dalam mengidentifikasi khalayak yang menjadi sasaran baik dari segi penentuan isi pesan maupun pemilihan media komunikasinya. Informan juga menilai perlu adanya pedoman, walaupun masih ada informan yang belum memahami secara jelas kebijakan/program yang dilaksanakan Kemenkes.

Hasil penelusuran informasi melalui website beberapa kementerian, hanya sebagian kecil yang sudah memiliki dan menerapkannya. Dari sekitar 34 kementerian atau lembaga setingkat kementerian, diluar Kementerian Pendayagunaan Aparatur Negara dan Reformasi Birokrasi (PAN-RB) dan Kementerian Kominfo, tercatat hanya3 kementerian yang sudah mempunyai pedoman komunikasi/ kehumasan dalam bentuk peraturan menteri, yakni Kementerian Perhubungan, Kementerian Dalam Negeri, dan Kementerian Kehutanan.

"Jadi saya melihatnya sangat bervariasi, pada K/L yang menterinya paham betul bagaimana sebuah fungsi komunikasi harus dijalankan, itu fungsi jubir dan humasnya jadi menonjol”. (Informan 6)

Berdasarkan hasil studi literatur diketahui terdapat beberapa peraturan perundangan yang seharusnya dijadikan acuan dalam melaksanakan program dan kegiatan komunikasi di Kementerian Kesehatan mulai dari Undang-undang, PP/Perpres, dan Peraturan/Keputusan Menteri.

Tahap selanjutnya identifikasi isu utama yang menjadi titik tolak berkembangnya suatu masalah menjadi masalah kebijakan. Kemunculan isu-isu yang beredar di tengah masyarakat dan di dalam institusi akan sangat mempengaruhi lahirnya atau bergantinya sebuah kebijakan publik. Berdasarkan hasil wawancara diketahui bahwa hanya isu-isu strategis yang berdampak luas yang akan diakomodir oleh para aktor berwenang (policy maker). Beberapa isu strategis yang berpotensi menjadi pendorong percepatan formulasi kebijakan komunikasi di Kemenkes, diantaranya adalah terbentuknya pemerintahan baru, adanya rencana perubahan organisasi (reorganisasi), era desentralisasi dan adanya konsep baru Humas pemerintah (Government Public Relations/GPR).

Beberapa isu lain, diantaranya adalah:1) posisi Humas dalam organisasi, 2) persepsi ten- tang peran dan kewenangan Humas; banyak yang beranggapan bahwa Humas bukanlah unit/bagian kerja yang dibutuhkan organisasi, 3) profesionalisme praktisi Humas; Humas dituntut untuk terus meningkatkan kompetensinya dan tanggap terhadap dinamika lingkungan di sekitarnya.

"Ya mungkin disini (Humas) gak terlalu dianggap penting ya, dan saya pikir juga pejabat-pejabat memahami bahwa PR itu, kadang di atas (pimpinan) sendiri gak paham kalo PR itu sangat penting”. (Informan 5)

Menurut informan, fungsi komunikasi yang dilakukan oleh Humas harusnya tidak hanya sampai pada tingkatan awareness saja, tetapi juga hingga terjadinya perubahan perilaku atau jika berupa kebijakan terhadap masyarakat agar berpartisipasi/turut serta mendukung implementasi kebijakan pemerintah.

Berdasarkan hasil penelusuran data sekunder diketahui bahwa Humas saat ini belum berada pada posisi yang strategis. Eksistensi Humas pemerintah di daerah yang tidak masuk ke dalam struktur organisasi di Satuan Kerja Pemerintah Daerah (SKPD) baik di tingkat Pemerintah Provinsi maupun di tingkat kabupaten/kota.

Selanjutnya agenda setting yang diidentifikasi berupa situasi politik dan birokrasi berpengaruh terhadap Humas dan fungsi komunikasi di bidang kesehatan, khususnya situasi politik internal (birokrasi). Berdasarkan hasil wawancara diketahui berbagai permasalahan dan isu yang ada di Puskomblik, juga telah dilakukan sejumlah alternatif solusinya. Diantaranya adalah melakukan kegiatan terobosan tidak hanya bekerja secara BAU (Business As Usual), membuat pedoman komunikasi/kehumasan dan memperkuat kemitraan dengan pihak-pihak terkait. Untuk mengatasi keterbatasan anggaran, SDM atau sarana yang ada, seperti memilih untuk melakukan kegiatan terobosan/inovatif ketimbang mencari-cari alasan tidak berjalannya kegiatan karena terlalu banyak hambatan.

Cara lain untuk menyiasati kekurangan atau keterbatasan adalah menjalin kerjasama kemitraan dengan pihak-pihak lain. Solusi lainnya dalam menghadapi permasalahan dan tantangan dalam 
menjalankan fungsi komunikasi di Kemenkes yakni pembuatan pedoman yang memuat strategi komunikasi, koordinasi, riset, pembiayaan dan sebagainya.

Pada bagian formulasi kebijakan komunikasi, menurut informan, isi kebijakan/pedoman komunikasi harus lengkap dan mengakomodir semua kepentingan. Ada juga yang berpendapat bahwa pengaturan detil tidak perlu masuk dalam pedoman, cukup dituangkan dalam bentuk Standard Operating Procedures (SOP).

Hal penting menurut informan yang dilakukan sebelum menentukan dan menetapkan isi pengaturan dalam kebijakan, adalah melakukan analisis situasi (SWOT), menyusun Key Performance Indicator (KPI) yang akan menjadi acuan dalam menyiapkan strategi dan unsur-unsur komunikasi lainnya, bisa juga dengan menyusun strategi ko- sudah dilakukan beberapa kali dan telah melibatkan beberapa pihak terkait seperti HumasHumas unit utama sebagai pelaksana dan tim pakar untuk memberikan masukan sesuai keahliannya masing-masing. Penyusunannya memakan waktu cukup lama dikarenakan harapan yang tinggi dari praktisi Humas di Kemenkes agar kebijakan (pedoman) tersebut berisi panduan lengkap. Yang terlewatkan adalah tahapan riset dan tidak melibatkan target audiens, sehingga pedoman ini tidak memiliki landasan yang kuat (research based) dan akan sulit untuk menjangkau sasarannya dan akan kembali pada pola kerja lama yang hanya komunikasi satu arah saja, tidak memperhatikan aspirasi kebutuhan di daerah dan masyarakat.

"Ekspektasi temen-temen Humas unit utama itu suatu buku tebal dan itu mengatur

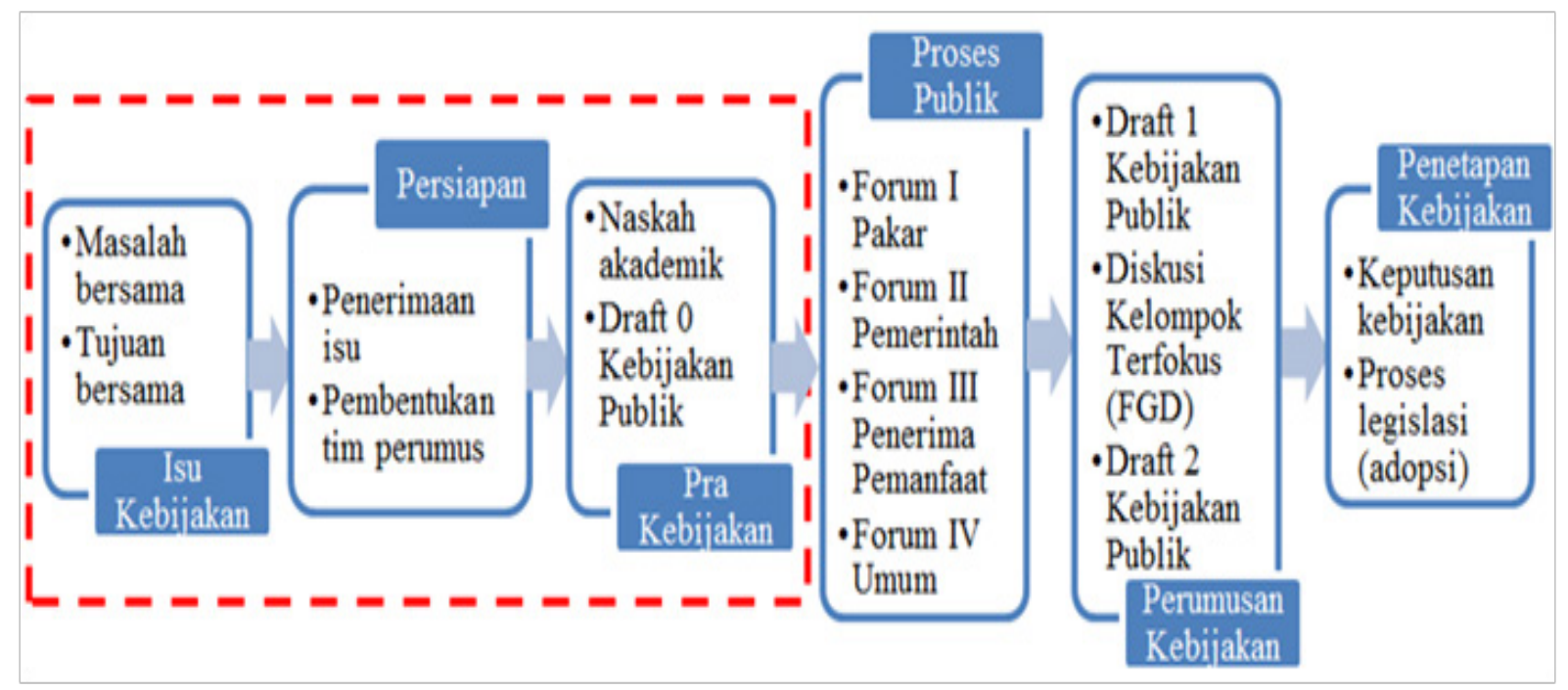

Sumber : Kemenag PAN, 2007

\section{Gambar 1. Skema Pedoman Formulasi Kebijakan Publik}

munikasi baru kemudian dijabarkan lebih lanjut.

Proses formulasi kebijakan publik sebagaimana diatur dalam pedoman umum formulasi, implementasi, evaluasi kinerja dan revisi kebijakan publik di lingkungan lembaga Pemerintah Pusat dan Daerah (Gambar 1). ${ }^{15}$ Apabila mengacu pada Permenpan ini, pada penelitian ini lingkup formulasi dibatasi hingga penyusunan draft 0 (nol) kebijakan karena adanya keterbatasan waktu dan kemampuan peneliti.

Proses penyusunan kebijakan (pedoman) segala macam dan akhirnya itu kan jadi gak selesai-selesai, 2 tahun loh itu gak selesai-selesai. Jadi sebetulnya pedoman ini sudah kaya cuma gak ada yang eksekusi karena kebanyakan masukan. Nah saya sudah men-challenge, harus sudah selesai tuh sebelum Biro Humas itu jadi, mungkin April keluar. Saya mohon itu sudah selesai. Itu sebetulnya. Kelamaan”. (Informan 1)

Komponen terakhir dalam formulasi kebijakan adalah mampu mengendalikan semua kegiatan 
perumusan kebijakan dan memutuskan isi kebijakan yang akan dihasilkan (decision maker). Selain para pembuat keputusan, ada pihak-pihak yang secara tidak langsung berpartisipasi, ada pula sebagian pihak lainnya yang menjadi pengguna/ penerima manfaat dari kebijakan yang dibuat. Semua informan menyatakan bahwa semua stakeholders, sebagai apapun kapasitasnya selama punya kepentingan harus diikutsertakan dalam proses pembuatan kebijakan, dalam hal ini pembuatan pedoman komunikasi/kehumasan di Kemenkes.

Intinya adalah stakeholders sebagai aktor yang terlibat, baik dalam kapasitasnya memengaruhi pembuatan kebijakan maupun sebagai penerima manfaat (beneficiaries) tidak hanya dalam proses pembuatan kebijakan, tetapi juga pada implementasi kebijakan tersebut nantinya, yang dalam hal ini adalah kebijakan komunikasi/kehumasan di Kemenkes.

Dapat diidentifikasi bahwa aktor kebijakan komunikasiini antara lain adalah: 1) Para pejabat pembuat keputusan (Menteri Kesehatan dan jajaran eselon I), pemberi arahan, dukungan dan komitmen; 2) Praktisi Humas di Kemenkes baik di pusat maupun di daerah, sebagai pengguna langsung kebijakan; 3) Kementerian PAN-RB dan Kementerian Kominfo, selaku lembaga pembina dan pengawas fungsi komunikasi yang dilakukan oleh seluruh kementerian/lembaga pemerintah; 4) Para pakar dan akademisi, selain sebagai tim ahli juga sebagai pengguna; 5) Perwakilan kelompok masyarakat, misalnya LSM, media atau komunitas pemerhati kesehatan, dan sebagainya. Semua pihak tersebut memiliki kepentingan dan pengaruhnya sendiri-sendiri yang patut diakomodir dalam kebijakan yang tengah disusun.

Tahap akhir penelitian dengan mengidentifikasi rekomendasi yang disampaikan berisi materi pokok yang terdiri dari tujuan, komunikator, pesan, media, komunikan dan strategi komunikasi. Tujuan komunikasi dalam konteks komunikasi institusi kepada publik internal maupun eksternal, setidaknya ada 3 jenis yakni: menyampaikan informasi, melakukan persuasi, dan memberikan edukasi.

Berdasarkan hasil penelitian diketahui bahwa permasalahan terjadi di semua komponen komunikasi mulai dari ketidaksesuaian antara tujuan ideal komunikasi yang ingin merubah perilaku masyarakat dengan yang selama dilakukan hanya sampai memberikan pemahaman, ketidakjelasan siapa yang menjadi komunikator, ketidakmampuan dalam mengemas pesan dan memilih media yang tepat, hingga tidak teridentifikasinya target audiens yang menjadi sasaran tiap program kesehatan bahkan diperberat dengan tidak adanya panduan.

"Semuanya penting. Tapi yang paling penting itu adalah pedoman (1) pemetaan khalayak baru kemudian (2) pengemasan isi informasinya baru pedoman (3) pemilihan media untuk menjangkau. 3 hal ini yang substantif". (Informan 3)

Secara garis besar rekomendasi kebijakan komunikasi memperhatikan unsur-unsur yang terkandung dalam sebuah proses komunikasi seperti siapa komunikatornya, bagaimana pengemasan pesannya, bagaimana memilih medianya dan seperti apa cara penyampaiannya serta bagaimana memetakan khalayak yang akan dituju. Selain itu tentu sebuah proses komunikasi harus diawali dengan penentuan tujuan dari komunikasi itu sendiri. Keberhasilan komunikasi juga tidak lepas dari strategi apa yang digunakan. Untuk itu selain standarisasi terhadap elemen-elemen komunikasi tersebut, perlu juga untuk menentukan tujuan dan menyiapkan strategi dalam berkomunikasi. Seluruh elemen tersebut dielaborasi lebih detil pada draft pedoman komunikasi di bagian strategi komunikasi.

Rekomendasi yang dihasilkan berbentuk draft pedoman komunikasi di Kemenkes berisi strategi komunikasi, serta secara rinci terdiri dari bagian-bagian yang membahas tentang komunikasi dan hubungan masyarakat, penyelenggaraan kegiatan-kegiatan komunikasi oleh hubungan masyarakat dan juga yang tidak kalah pentingnya tentang materi pembinaan, pembiayaan, monitoring, evaluasi dan audit komunikasi.

\section{PEMBAHASAN}

Komunikasi dan informasi telah berperan banyak dalam mendukung keberhasilan pembangunan nasional. Tanpa adanya komunikasi yang dilakukan pemerintah, kebijakan dan program yang digulirkan tidak akan banyak diketahui masya- 
rakat. Masyarakat yang tidak mengetahui kebijakan dan memahami program pemerintah kemungkinan besar tidak akan turut berpartisipasi dalam melaksanakan kebijakan dan program pemerintah, baik pemerintah pusat maupun pemerintah daerah.

Masalah kebijakan adalah suatu situasi atau kondisi yang menghasilkan kebutuhan dan ketidakpuasan di masyarakat sehingga memerlukan solusi dari pemerintah. ${ }^{16}$ Menurut Kingdon inilah yang disebut penetapan agenda (agenda setting) yang dapat pula dikatakan sebagai daftar subyek atau masalah yang menjadi perhatian serius pihak pemerintah atau kalangan di luar pemerintahan dalam suatu waktu tertentu. ${ }^{11}$ Fase ini menghasilkan pemilihan diantara masalah dan isu yang beragam. Sebuah proses membangun isu kebijakan berkenaan dengan strategi potensial dan instrumennya yang mampu mengembangkan kebijakan dalam tahapan berikutnya dari siklus kebijakan. ${ }^{17}$

Pada proses perancangan kebijakan, terdapat sebuah fase yang sangat menentukan keberhasilan sebuah kebijakan yang dihasilkan, yaitu fase formulasi/perumusan kebijakan. Proses mengacu kepada cara bagaimana kebijakan dimulai, dikembangkan atau disusun, dinegosiasi, dikomunikasikan, dilaksanakan dan dievaluasi. Pada tahap formulasi kebijakan, masalah yang masuk ke dalam agenda kebijakan dibahas untuk mencari alternatif pemecahan masalah terbaik. Sama halnya seperti dalam perjuangan suatu isu masuk ke dalam agenda setting, dalam tahap formulasi, setiap alternatif juga bersaing untuk dapat dipilih menjadi prioritas keputusan guna menyelesaikan masalah. ${ }^{6}$

Pada bidang kesehatan, terdapat suatu studi yang secara khusus mempelajari cara menggunakan komunikasi untuk menyebarluaskan informasi kesehatan yang dapat memengaruhi individu dan komunitas dalam membuat keputusan untuk hidup sehat. Komunikasi jenis ini meliputi informasi tentang pencegahan penyakit, promosi kesehatan, kebijakan kesehatan, regulasi kesehatan yang sedapat mungkin mengubah dan memperbaharui kualitas kesehatan setiap individu atau masyarakat. Studi ini meliputi komunikasi persuasif yang berdampak pada perubahan perilaku masyarakat dan faktor-faktor psikologis individual dalam hal persepsi terhadap kesehatan. ${ }^{17}$

Kementerian Pendayagunaan Aparatur
Negara dan Reformasi Birokrasi dan Kementerian Komunikasi dan Informatika selaku penanggung jawab Unit Hubungan Masyarakat di instansi pemerintah telah menerbitkan sejumlah regulasi yang seharusnya dijadikan referensi oleh seluruh Kementerian/Lembaga baik di pusat maupun di daerah untuk mengatasi beban permasalahan internal, dan untuk membangun serta meningkatkan fungsi komunikasi dan manajemen kehumasan di instansi pemerintah agar pelaksanaannya dapat lebih efektif, efisien dan optimal.

Pada proses formulasi kebijakan salah satunya terdapat konsep penetapan kebijakan sebagai sebuah sistem yang digambarkan oleh Easton. Sebuah sistem yang dipengaruhi oleh faktor-faktor sosial, politik, ekonomi, sejarah dan faktor eksternal lainnya tak terkecuali pula faktor internal yang memengaruhi para aktor, stakeholders atau penentu kebijakan yaitu nilai-nilai, kepentingan, juga pilihan-pilihan dipengaruhi oleh perilaku dan kepribadian mereka. Kesemuanya akan berperan signifikan dalam proses pembuatan kebijakan hingga memungkinkan terjadinya tarik-menarik kepentingan antara aktor, interaksi kekuasaan, alokasi sumber daya dan bargaining position di antara pelaku yang terlibat dalam sebuah kotak hitam penetapan kebijakan. ${ }^{19}$ Mengetahui aktor (stakeholders) yang terlibat menjadi hal penting mengingat mereka yang akan menentukan nasib kebijakan akan seperti apa. ${ }^{6}$

Hasil penelitian menunjukkan permasalahan dalam fungsi komunikasi/kehumasan yang perlu diprioritaskan dan perlu segera ditangani, yaitu: Sumber Daya Manusia, prosedur dan mekanisme kerja, posisi dan peranan Humas yang berada pada posisi strategis dalam struktur organisasi dan terlibat dalam berbagai penentuan kebijakan organisasi dan akan meningkatkan kontribusinya terhadap keberlangsungan organisasi. Humas harus mampu membangun dirinya agar dianggap sebuah investasi dan bukan hanya pengeluaran yang tidak memiliki korelasi dengan tujuan organisasi/lembaga pemerintah. ${ }^{20}$

Alternatif solusi dari beberapa isu dan masalah bidang komunikasi tersebut dengan urutan prioritas yang termudah untuk dilakukan yakni: 1) menyusun strategi komunikasi yang tepat. Strategi ini merupakan metode yang digunakan untuk mencapai tujuan komunikasi dan juga output ser- 
ta outcome dari sebuah program komunikasi, 2) membuat pedoman/panduan kegiatan komunikasi/ Humas, 3) menerapkan konsep Government Public Relations (GPR). Solusi ini bisa dilakukan bertahap dan menjadi prioritas terakhir. Konsep GPR di Indonesia sendiri masih butuh penyesuaian untuk bisa diterapkan secara utuh.

Hasil penelitian menunjukkan permasalahan yang terjadi di semua aspek komunikasi mulai dari ketidaksesuaian antara tujuan ideal komunikasi yang ingin merubah perilaku masyarakat dengan yang selama dilakukan hanya sampai memberikan pemahaman, ketidakjelasan siapa yang menjadi komunikator, ketidakmampuan dalam mengemas pesan dan memilih media yang tepat, hingga tidak teridentifikasinya target audiens yang menjadi sasaran tiap program kesehatan bahkan diperberat dengan tidak adanya panduan dalam menyusun strategi komunikasi yang efektif dan efisien, maka semakin jelaslah bahwa hadirnya pedoman komunikasi saat ini sangat dibutuhkan.

Hasil pembandingan dengan kebijakan komunikasi yang telah ada, serta kajian sejumlah literatur, baik berupa peraturan perundangundangan seperti yang sudah dijelaskan pada bagian sebelumnya maupun beberapa dokumen khusus komunikasi beberapa lembaga dan referensi lainnya, ditambah lagi sebagian juga diadaptasi dari draft pedoman yang sudah disiapkan oleh Puskomblik Kemenkes. Selanjutnya disusun dan disajikan sejumlah materi yang berisi substansi pengaturan dari draft pedoman komunikasi yang akan direkomendasikan kepada Puskomblik Kemenkes.

Secara garis besar, rekomendasi kebijakan komunikasi ini memperhatikan unsur-unsur yang terkandung dalam sebuah proses komunikasi seperti siapa komunikatornya, bagaimana pengemasan pesannya, bagaimana memilih medianya dan seperti apa cara penyampaiannya serta bagaimana memetakan khalayak yang akan dituju. Selain itu tentu sebuah proses komunikasi harus diawali dengan penentuan tujuan dari komunikasi itu sendiri. Keberhasilan komunikasi juga tidak lepas dari strategi apa yang digunakan. Untuk itu, selain standarisasi terhadap elemen-elemen komunikasi tersebut, perlu juga untuk menentukan tujuan dan menyiapkan strategi dalam berkomunikasi. Kesemua elemen tersebut dielaborasi lebih detil pada draft pedoman komunikasi di bagian strategi komunikasi.

Rekomendasi yang berbentuk draft pedoman komunikasi di Kementerian Kesehatan tersebut selain berisi strategi komunikasi juga secara rinci terdiri dari bagian-bagian yang membahas tentang komunikasi dan hubungan masyarakat, penyelenggaraan kegiatan-kegiatan komunikasi oleh hubungan masyarakat dan juga yang tidak kalah pentingnya tentang materi pembinaan, pembiayaan, monitoring, evaluasi dan audit komunikasi.

\section{KESIMPULAN DAN SARAN}

Fungsi komunikasi yang dijalankan oleh Puskomblik Kementerian Kesehatan telah mengalami kemajuan, tetapi masih ada permasalahan dan tantangan internal maupun eksternal, antara lain belum memiliki pedoman komunikasi yang dijadikan acuan dalam mengarahkan, mengendalikan dan mengevaluasi pelaksanaan tugas dan fungsinya sehari-hari dan mengatur hal-hal kehumasan yang mendasar dan menyeluruh. Saat penelitian ini dilakukan, Puskomblik Kemenkes sedang menginisiasi penyiapan kebijakan komunikasi yang berisi materi kehumasan secara umum.

Penelitian ini menghasilkan draft pedoman komunikasi yang diharapkan dapat melengkapi draft pedoman yang sedang dipersiapkan oleh Puskomblik Kemenkes. Rekomendasi bagi Puskomblik Kementerian Kesehatan agar dapat mempercepat proses penyelesaian pembuatan kebijakan komunikasi, menetapkannya dalam bentuk Peraturan Menteri Kesehatan dan mensosialisasikannya ke seluruh unit kerja di Kementerian Kesehatan dan unit terkait di daerah sehingga bisa segera diterapkan. Selain itu juga agar dapat meningkatkan kapasitas dan alokasi sumber daya yang dibutuhkan terutama dalam hal SDM dan anggaran. Rekomendasi untuk instansi lain yang terkait, supaya dapat membuat kebijakan untuk memperkuat posisi dan peran Humas pemerintah.

\section{DAFTAR PUSTAKA}

1. Edward III GC. Implementing Public Policy. Washington: Quarterly Press;1980.

2. Kementerian Kesehatan RI. Riset Kesehatan Dasar 2013. Jakarta: Badan Penelitian dan Pengembangan Kesehatan; 2013. 
3. Badan Pusat Statistik. Survei Demografi Kesehatan Indonesia. Jakarta: Badan Pusat Statistik RI; 2012.

4. Suryaningsih C. Pengaruh Pendidikan Kesehatan terhadap Pengetahuan Ibu Post Partum tentang ASI Eksklusif. Jurnal Keperawatan Soedirman. 2013;8(2):77-86

5. WHO. Global Adult Tobacco Survey: Indonesia Report 2011. India: WHO, Regional Office for South East Asia; 2012.

6. Winarno B. Kebijakan Publik (Teori, Proses dan Studi Kasus). Yogyakarta: CAPS; 2012.

7. Peraturan Menteri Kesehatan Nomor $1144 \mathrm{Ta}-$ hun 2010 tentang Organisasi dan Tata Kerja Kementerian Kesehatan. Jakarta: Kementerian Kesehatan RI.

8. Kriyantono R. Teknik Praktis Riset Komunikasi. Jakarta: Kencana Prenada Media Group; 2012.

9. Ghony, M,\& Almanshur, F. Metode Penelitian Kualitatif. Jakarta: Ar-Ruzz Media; 2012.

10. Ayuningtyas D. Kebijakan Kesehatan: Prinsip dan Praktik. Jakarta: Rajawali Pers; 2014.

11. Kingdon JW. Agenda, Alternatives and Public Policies. London: Pearson Education Limited; 2014.

12. Buse, K, Mays, N. \& Walt, G. Making Health Policy, Understanding Health Policy.New York: Open University Press; 2005.
13. Ardianto, E., Komala, L. \& Karlinah, S. Komunikasi Massa, Suatu Pengantar. Bandung: Simbiosa Rekatama Media; 2014.

14. Wibowo A. Metodologi Penelitan Praktis Bidang Kesehatan. Jakarta: Rajawali Pers; 2014.

15. Peraturan Menteri Negara PAN Nomor PER/4/M.PAN/4/2007 tentang Pedoman Umum Formulasi, Implementasi, Evaluasi Kinerja dan Revisi Kebijakan Publik di Lingkungan Pemerintah Pusat dan Daerah. Jakarta: Kementerian Negara Pendayagunaan Aparatur Negara. 2007.

16. Anderson JE. Public Policymaking: an Introduction. Boston USA: Houghtin Miffin Company; 2003.

17. Fischer, F., Miller, G. J. \& Sidney, M. S. Handbook of Public Policy Analysis; Theory, Politics and Methods. USA: CRC Press;2007.

18. Liliweri A. Dasar-Dasar Komunikasi Kesehatan. Jakarta: Pustaka Pelajar; 2007.

19. Ayuningtyas D. Kotak Hitam Sistem Penetapan Kebijakan dan Faktor-Faktor yang Mempengaruhinya. Jurnal Manajemen Pelayanan Kesehatan. 2008;11(2):44-48.

20. Wasesa, S. A. \& Macnamara, J. Strategi Public Relations. Jakarta: Gramedia Pustaka Utama; 2010. 